\title{
N-BANDING AND NUCLEOLUS ORGANISERS IN ASELLUS AQUATICUS (CRUST. ISOP.)
}

\author{
M. Di CASTRO, G. PRANTERA, E. MARCHETTI and A. ROCCHI \\ Centro di Genetica Evoluzionistica del C.N.R. and Instituto di Genetica dell' \\ Universita, di Roma
}

Received 2.xii.76

\begin{abstract}
SUMMARY
The $\mathcal{N}$-banding technique was used to stain the nucleolus organiser of the karyotype of Asellus aquaticus (Crust. Isop.). Observations were made on the morphological expression of nucleolus organisers as secondary constrictions and the presence of nucleoli in mitotic prophase. An attempt was made to correlate the various results and it seems likely that $\mathcal{N}$-banding is not a reflection of $\mathcal{N O}$ activity.
\end{abstract}

\section{Introduction}

Iт has been known for many years (Heitz, 1931) that secondary chromosome constrictions are often " nucleolus organisers", that is the genetic site for ribosomal RNA (Brown and Gurdon, 1964; Ritossa and Spiegelman, 1965; etc.). Nucleolus organisers have been extensively studied both at a molecular and a cytological level.

Moreover, it has been observed that, while their location is constant in the karyotype of individuals of the same species, there exists a variability in their morphological expression as a secondary constriction in metaphase; it has in fact been observed that the number and size of these constrictions can vary from individual to individual of the same species, from cell to cell of the same individual and between homologous chromosomes (Ohno et al., 1961; Keep, 1962; Hsu et al., 1967; Miller and Brown, 1969; etc.). There are basically two explanations of these phenomena; either the length of a nucleolus constriction in metaphase reflects the state of activity of the nucleolus organiser in the preceding interphase (Ohno et al., 1.961; Keep, 1962; Wallace and Langridge, 1971; etc.) or it is a consequence of the number of ribosomal genes present (Ritossa et al., 1966; Bross et al., 1973; Elsevier and Ruddle, 1975; etc.). The two explanations are valid and both singly and together can explain the various situations to be seen in different species and in different tissues.

Recently, two techniques that specifically stain the nucleolus organiser regions have been developed; the first, known as $\mathcal{N}$-banding, has been tested with good results on the chromosomes of many animal and plant species (Matsui and Sasaki, 1973; Funaki et al., 1975); it gave contrasting results, however, in some species of Drosophila (Pimpinelli et al., 1976); the second, called the $A g-A S$ technique, gave good results on the chromosomes of some species of mammals (Goodpasture and Bloom, 1975).

For this second technique the hypothesis was put forth that the nucleolus organiser staining is linked to the capacity of the rRNA genes of being transcribed (Tantravahi et al., 1976; Miller et al., 1976). The authors 
think that both techniques stain proteins-probably acidic-which are specific to the nucleolus organiser.

We have used the $\mathcal{N}$-banding method on chromosomal preparations of Asellus aquaticus and have at the same time made a study of secondary constrictions and nucleoli in the cells of this crustacean. In the karyotype of Asellus aquaticus $(2 n=16)$ (pl. II, fig. 7) two pairs of chromosomes with a subterminal secondary constriction and therefore satellites can be observed. One pair, no. 7, is easily identified, and the other is located in the 2-6 group (Rapenne, 1973). An attempt to better identify these chromosomes with the $G$ - and $Q$-banding techniques gave no appreciable results (Di Castro et al., 1973).

Our research was aimed at detecting the existence of any direct relationship between evidence of secondary constrictions, functioning of the nucleolus organiser and staining of the same by $\mathcal{N}$-banding.

\section{Materials AND MEthods}

The study was carried out on preparations of the testes of Asellus equaticus (Crust. Isop.) obtained by squashing. Some of the individuals were injected with colchicine $(0.05$ per cent) before sectioning. Suitable preparations were treated with the $\mathcal{N}$-banding technique (Funaki et al., 1975).

Others were sectioned without pretreatment with colchicine. Suitable preparations were stained with methyl green pyronine. Acetic acid (45 per cent), Carnoy (ethyl alcohol and acetic acid, $2: 1$ ) and 10 per cent neutral formalin were used as fixatives. Some 200 slides were examined.

\section{Results}

In most of the cells observed, both in prometaphase and in metaphase, there are secondary constrictions evident, usually those of chromosome pair no. 7, which often occur together (pl. II, fig. 7); chromosomes of pair 2-6, in fact, rarely showed the secondary constriction.

The secondary constriction of pair no. 7 is located in an almost terminal position and the satellite of this chromosome pair is therefore very small (pl. I, fig. 1); the satellite of pair 2-6 is, on the other hand, larger, that is, the secondary constriction is less terminal (pl. I, figs. 1 and 2). In cells of the same individual the secondary constrictions of both pairs appeared in different numbers, combinations and dimensions.

There are usually two (sometimes one) nucleoli present in mitotic prophase, as in interphase (pl. I, fig. 3), and these are each associated with a chromosome in the terminal position (pl. I, fig. 4). The identification of these two prophase chromosomes is not easy. In most cases we are dealing with no. 7 chromosomes, but we cannot cxclude the fact that sometimes one of these belongs to the 2-6 pair.

With the $\mathcal{N}$-banding technique selective staining was obtained of a subterminal area of a chromosome pair of the 2-6 group (pl. II, fig. 1) and of an apparently terminal area of pair no. 7 (pl. I, fig. 6).

These areas never all stain simultaneously. The most frequent case was that in which a single chromosome per cell was $\mathcal{N}$-banded. The maximum number of $\mathcal{N}$-bands to appear in the same cell was 3 (pl. I, fig. 5). The combinations in which the $\mathcal{N}$-banded chromosomes appeared were 

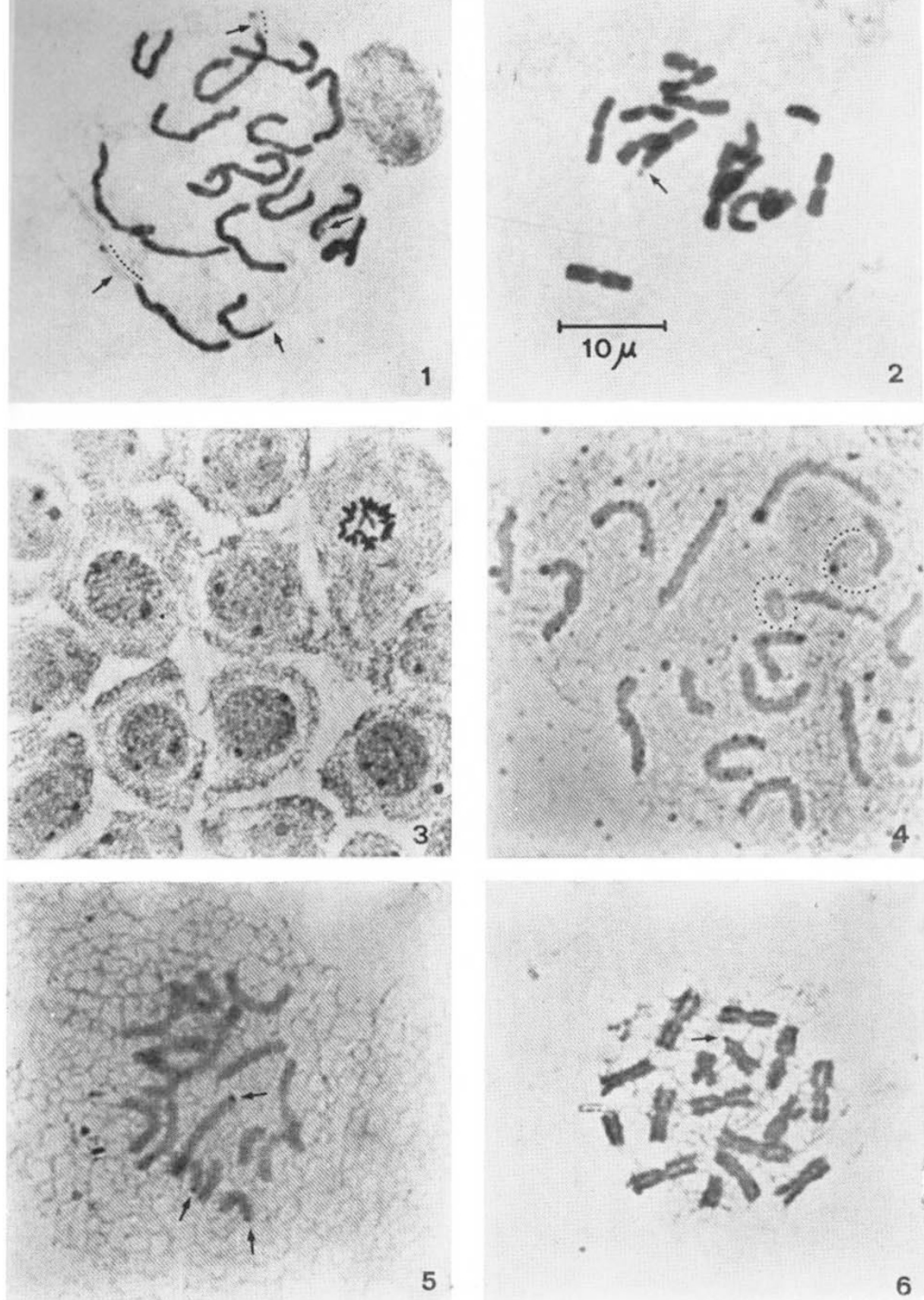

Plate I

Fig. 1.-Gonial mitotic prophase. The arrows indicate the secondary constrictions.

FIG. 2.-Gonial mitotic metaphase. The arrow indicates the secondary constriction of a 2-6 chromosome.

Fig. 3.-Gonial cells. In the interkinetic nuclei two nucleoli can usually be seen.

Fig. 4.-Gonial mitotic prophase. Two nucleoli associated with two chromosomes can be seen.

Fig. 5.-Gonial mitotic metaphase. The arrows indicate the $\mathcal{N}$-bands on two chromosomes no. 7 and on one no. 2-6 chromosome.

Fig. 6.- Gonial mitotic metaphase. The arrow indicates the $\mathcal{N}$-band on one no. 7 chromosome. 

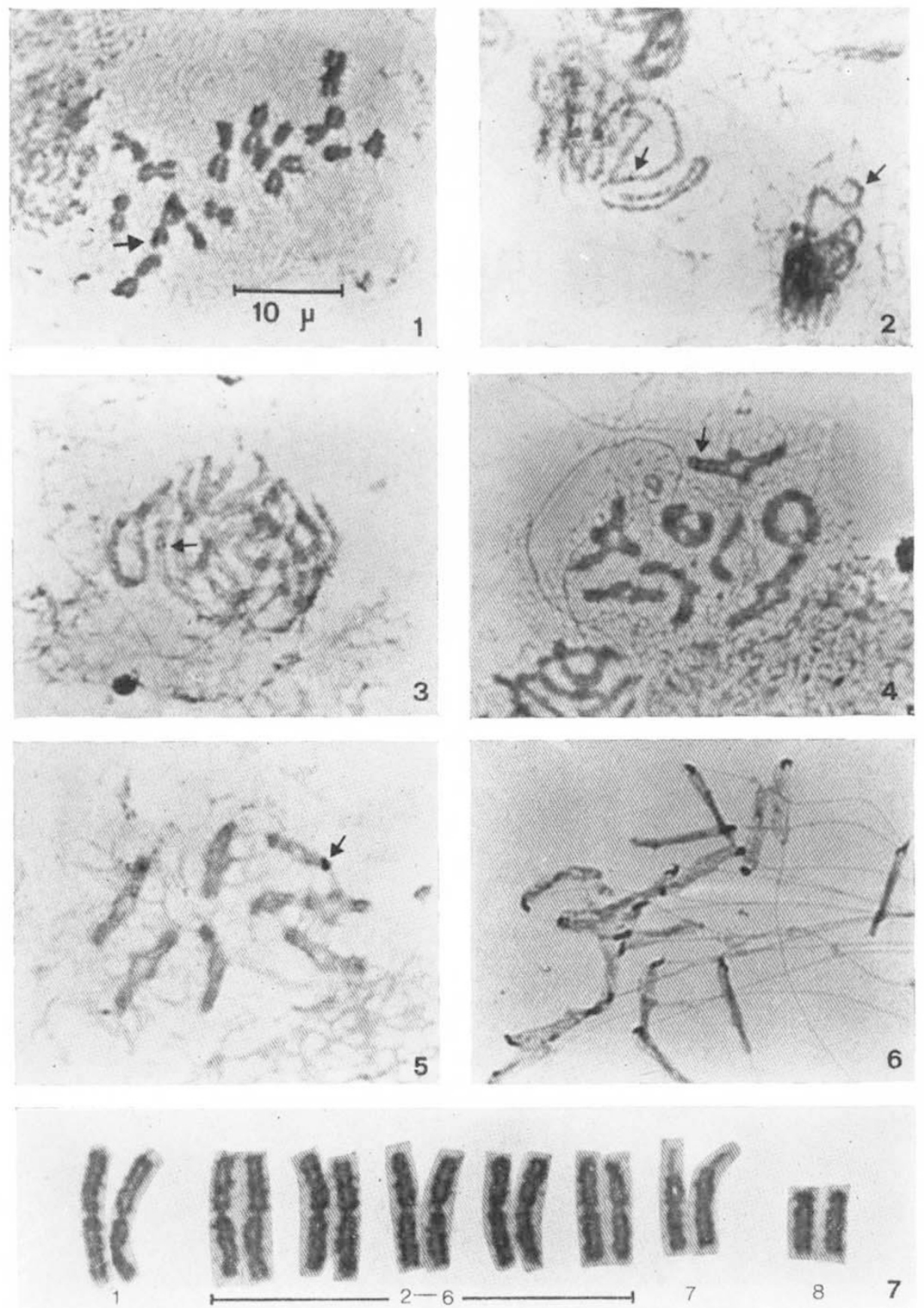

Plate II

Fig. 1.-Gonial mitotic metaphase, The arrow indicates the $\mathcal{N}$-band on one 2-6 chromosome.

Figs. 2 and 3.-Pachytene cells. The arrows indicate the $\mathcal{N}$-bands on one pair of chromosomes per cell.

Figs. 4 and 5.-Diakinesis cells. The arrow indicates the $\mathcal{N}$-bands on one chromosome 2-6 (fig. 4) and 7 (fig. 5).

Fig. 6.--Spermatozoa with part of head heavily stained after treatment for $\mathcal{N}$-bands.

FIG. 7.- Caryogram from gonial mitotic cell with secondary constrictions only on chromosome pair no. 7 . 

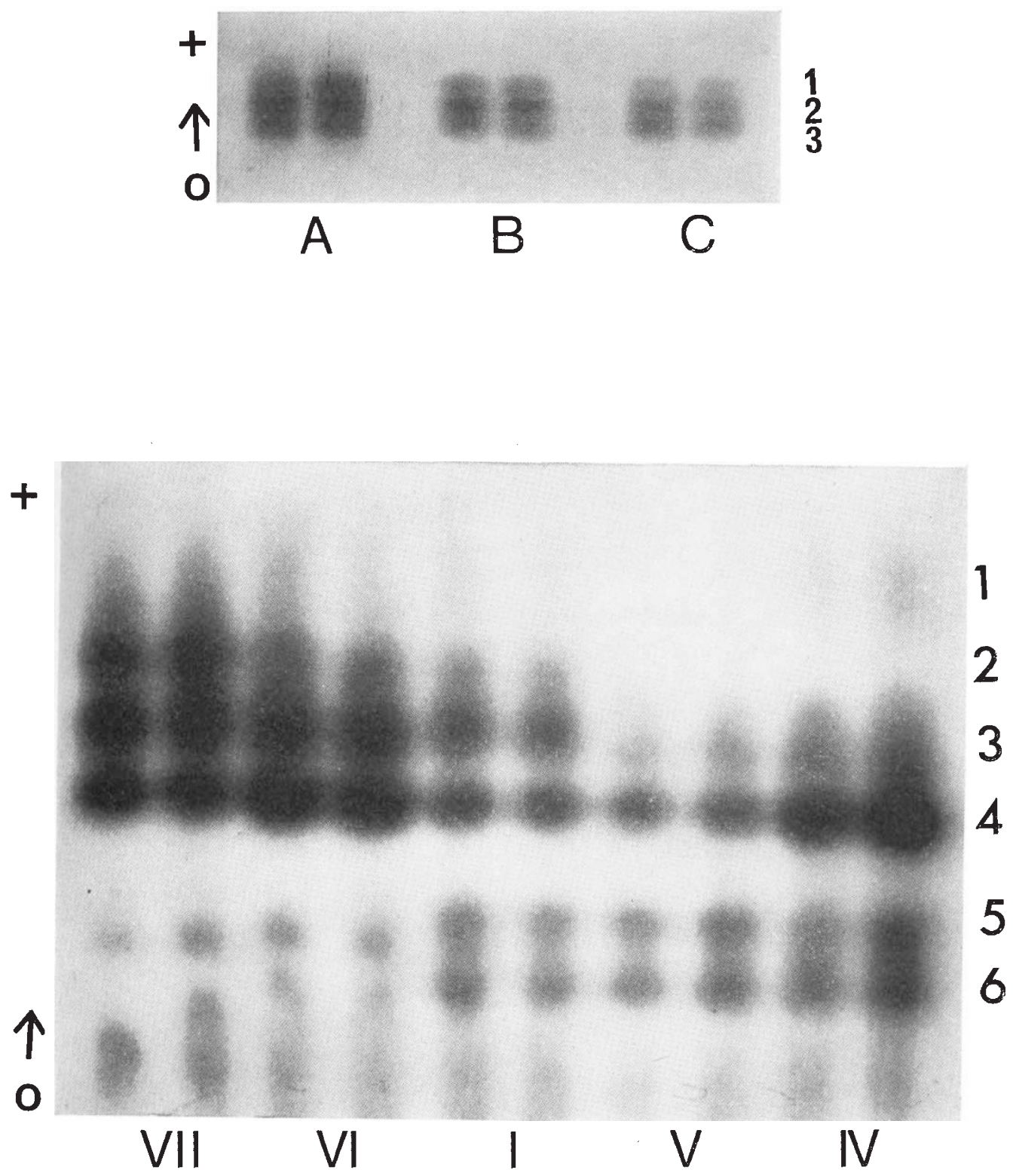

Plate 1, Fig. 1.--Photograph of the ADH zymogram phenotypes produced by (A) strain PI 226951 of the tetraploid wheat $T$. turgidum $(2 n=28$, genomes A and B), (B) the ditelo-4DL derivative of the $\mathcal{T}$. aestivum cultivar "Chinese Spring", and (C) euploid "Chinese Spring". The bands of ADH activity are identified by the numbers to the right. Migration was toward the anode from the origin, as indicated by the arrow.

Plate 1, FIG. 2.-Photograph of ACPH zymogram phenotypes observed. I: "Chinese Spring". IV: Nulli-4B tetra-4A. V: Nulli-4B tetra-4D. VI: Nulli-4D tetra-4A. VII: Nulli-4D tetra-4B. The bands of ACPH activity are identified by the numbers to the right. Migration was toward the anode from the origin, as indicated by the arrow. 
different in cells of the same individual. On the whole the chromosomes of the two pairs presented the same frequency of $\mathcal{N}$-bands. $\mathcal{N}$-bands were observed also in meiotic chromosomes: in late diakinesis and first metaphase on a single chrosome of a bivalent (pl. II, figs. 4 and 5) and, at pachytene, on a single chromosome pair (pl. II, figs. 2 and 3 ), the location was always subterminal or terminal. After treatment for $\mathcal{N}$-bands the base of the head of the spermatozoa of Asellus aquaticus constantly stains bright red (pl. II, fig. 6).

\section{Discussion}

We can draw a certain number of conclusions from our observations. Since the $\mathcal{N}$-bands appear on the chromosomes of Asellus aquaticus corresponding to the areas in which the secondary constrictions are observed and the same occurs for the nucleoli observed in the late mitotic prophase, we can conclude that in this organism the secondary constrictions are the site of the nucleolus organiser and that this is selectively stained by the $\mathcal{N}$-banding technique. The fact that sometimes the $\mathcal{N}$-bands are observed in a terminal position, above all on the chromosome of the no. 7 pair, is most likely due to the drastic method and small size of the satellites of this chromosome pair which, even with normal staining, is only slightly evident.

Since the secondary constrictions are usually evident on the chromosomes of pair no. 7 and nucleoli in prophase are more often observed associated with precisely these chromosomes, we think that the evidence of a secondary constriction on the prophase chromosomes and metaphase chromosomes of Asellus aquaticus reflects the state of activity of the $\mathcal{N O}$; however it cannot be excluded that it may be the effect of a longer permanence here of the nucleolus which could have been organised with the co-operation, in interkinesis, of more nucleolus organisers.

Because of this latter possibility, that is that a nucleolus organiser can function in interphase and then undergo normal chromosomal spiralisation and not be therefore detectable either in prophase associated to a nucleolus or in metaphase as a secondary constriction, it is difficult to attempt a correlation between function and staining of the $\mathcal{N} O$ with $\mathcal{N}$-bands (Tantravahi et al., 1976). If we instead accept that the secondary constriction is the constant index of the activity of the nucleolus organiser, from our data we can deduce that the presence of $\mathcal{N}$-bands in Asellus is not related to the function. They appear, equally on both chromosomes-a quite different distribution from that of secondary constrictions. We must also deduce that in Asellus the nucleolus organisers present in pair no. 7 are those which function more often, that is whose genes for rRNA are usually transcribed, while the nucleolus organisers present in pair 2-6 function more rarely. This latter fact seems to recall the idea of some authors concerning the existence of strong and weak nucleolus organisers (Brown and Blackler, 1972) and in any case the existence of gross genetic controls which allow large numbers of rRNA genes to be switched on or off (Miller and Knowland, 1972).

Preferential staining of the nucleolus organisers as well as of part of the head of the mature sperm of Asellus aquaticus, is a constant finding and, it would seem to us, a very interesting one. We are in fact wondering what these two areas have in common which would cause them to be the only 
ones stained by this techniques, particularly as the head of the sperm of Asellus should not contain acidic proteins (Rocchi Brasiello, 1971).

\section{REFERENCES}

BROSS, K., DITTES, H., KRONE, W., SCHMID, M., AND VOGEL, w. 1973. Biocheinical and cytogenetic studies on the nucleolus organizing regions (NOR) of man. I. Comparison of trisomy 21 with balanced translocations $\mathrm{t}(\mathrm{Dq} \mathrm{Gq})$. Humangenetik, 20, 223-229.

BROWN, D. D., AND BLACKLER, A. W. 1972. Gene amplification proceeds by a chromosome copy mechanism. 7. Mol. Biol., 63, 75-83.

BROWN, D. D., AND GURDON, J. B. 1964. Absence of ribosomal RNA synthesis in the anucleolate mutant of Xenopus laevis. Proc. $\mathcal{N}$ atl. Acad. Sci., 51, 139-146.

DI CASTRO, M., MARCHETTI, E., AND ROCCHI BRASIEllo, A. 1973. Studio del cariotipo di Asellus aquaticus per mezzo delle tecniche della tripsina e della fluorescenza. Acc. Naz. Lincei, 55, 116-118.

ELSEVIER, S. M. AND RUDDle, F. H. 1975. Location of genes coding for $18 \mathrm{~S}$ and $28 \mathrm{~S}$ ribosomal RNA within the genome of Mus musculus. Chromosoma (Berl.), 52, 219-228.

FUNAKI, K., MATSUI, s. AND SASAKI, M. 1975. Location of nucleolar organizers in animal and plant chromosomes by means of an improved $\mathrm{N}$-banding technique. Chromosoma (Berl.), 49, 357-370.

GOODPASTURE, C., AND BLOOM, S. E. 1975. Visualization of nucleolar organizer regions in mammalian chromosomes using silver staining. Chromosoma (Berl.), 53, 37-50.

Hertz, e. 1931. Die Ursache der gesetzmässigien Zahl, Loge. From und Grösse pllanzlicher Nukleolen. Planta (Berl.), 12, 774-844.

HSU, T. C., BRINKLEY, B. R. AND ARRIGHI, F. E. 1967. The structure and behavior of the nucleolus organizers in mammalian cells. Chromosoma (Berl.), 23, 137-153.

KEEP, E. 1962. Satellite and nucleolar number in hibrids between Ribes nigrum and Ribes grossularia and their backcrosses. Can. F. Genet. Cytol., 4, 206-218.

MATSUI, S., AND SASAKI, M. 1973. Differential staining of nucleolus organizers in mammalian chromosomes. Nature, 246, 148-150.

Miller, D. A., DEV, v. G., TANTRAVAHI, R. AND MilleR, O. J. 1976. Suppression of human nucleolus organizer activity in mouse-human somatic hybrid cells. Exp. Cell Res., 101, 235-243.

MILLER, L. AND BROWN, D. D. 1969. Variation in the activity of nucleolar organizers and their ribosomal gene content. Chromosoma (Berl.), 28, 430-444.

MILLER, L. AND KNOWLAND, J. 1972. The number and activity of ribosomal RNA genes in Xenopus laevis embryos carrying partial deletions in both nucleolar organizers. Biochem. Genet., 6, 65-73.

OHNO, s., WEILER, C. AND sTeNius, c. 1961. A dormant nucleolus organizer in the guinea pig Cavia cobaya. Exp. Cell Res., 25, 498-504.

PIMPINELLI, s., SANTINI, G., AND GATTI, м. 1976. Characterization of Drosophila heterochromatin. II. C- and N-banding. Chromosoma (Berl.), 57, 377-386.

RAPENNe, F. 1973. Etude du comportement des chromosomes nucléoligènes chez Asellus (Proasellus) meridianus Racovitza et Asellus aquaticus Linné. C. R. Acad. Sc. Paris, 276, 3331-3334.

Ritossa, F. M., Atwood, K. C., ANd spiegelman, s. 1966. A molecular explanation of the bobbed mutants of Drosophila as partial deficiencies of "ribosomal "DNA. Genetics, 54, 819-834.

RiTOSSA, F. M. and SPIEGElmAN, s. 1965. Location of DNA complemicntary to ribosomal RNA in the nucleolus organizer region of Drosophila melanogaster. Proc. Natl. Acad. Sci., $53,737-745$.

ROCCHI BRASIELLO, A. 1971. Protein synthesis during spermatogenesis of Asellus aquaticus. Exp. Cell Res., 67, 279-288.

TAN'TRAVAhi, R., Miller, D. A., DEV, V. G., AND Miller, o. J. 1976. Detection of nucleolus organizer rcgions in chromosomes of human, chimpanzee, gorilla, orangutan and gibbon. Chromosoma (Berl.), 56, 15-27.

WALLACE, H. AND LANGRIDGE, w. H. R. 1971. Differential amphiplasty and the control of ribosomal RNA synthesis. Heredity, 27, 1-13. 